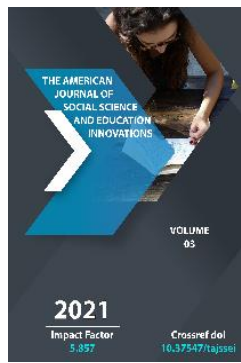

\title{
Issues In Explaining Mixed Conditionals To EFL Learners
}

Jumaniyozova Feruza Tulibayevna

The EFL/ESL Teacher Of The Uzbekistan State World Languages University, Tashkent, Uzbekistan

Journal Website:

http://usajournalshub.c

om/index,php/tajssei

Copyright: Original content from this work may be used under the terms of the creative commons attributes 4.0 licence.

\section{ABSTRACT}

In introducing conditionals to the students, teachers come across difficulties, as it is hard to explain this grammar rule without mentioning form, meaning, and time-tense relationship separately. Since the conditionals themselves are a complicated topic for both teachers and learners, mixed conditionals raise more confusion among L2 learners in Uzbekistan. Therefore, mixed conditionals are one of the most troublesome issues that EFL learners struggle to understand and use. This article focuses on (1) learners' difficulties in understanding this grammar rule and (2) easier ways of explaining mixed conditionals to the students with the help of focus-on-form and focus-on-meaning activities.

\section{KEYWORDS}

Mixed conditionals, inductive teaching, deductive teaching, time-tense relationship, focus-on-form, focus-on-meaning, L2 learners

\section{INTRODUCTION}

Because of the internal complexity, conditionals always confuse EFL learners because many textbooks lack a precise explanation of conditionals: their meaning and their usage in the context. The EFL textbooks provide information about the three main 
types of conditionals, so understanding mixed conditionals is even more challenging for $\mathrm{L} 2$ learners. Using mixed conditionals raises confusion among EFL learners because of their form, meaning, oversimplified explanation, and time-tense relationship. Many textbooks do not provide enough information about mixed conditionals; therefore, using mixed conditionals is not common among L2 learners in Uzbekistan.

\section{LITERATURE REVIEW}

Upon teaching mixed conditionals, a language instructor should make sure that the learners comprehend the three main types of conditionals: factual, hypothetical, counterfactual (Taylor, 1997); so, it can be easier to explain mixed conditionals to them. Celce-Murcia and Larsen Freeman (1999) provide several factors that contribute to the toughness of conditional sentences for EFL and ESL learners. They also state that some grammarians believe that there are three main types of conditionals that are used in everyday English; however, according to the corpus of American English, there are other types of conditionals, such as mixed conditionals, used in real-life situations. Many grammar books provide information about only three main types (J. Dooley \& V. Evans, 1999; R. Murphy, 2012; S. Kay \& V. Jones, 2009).

According to Covit (1976), there are four primary aspects where why EFL and ESL learners face difficulty in learning, and they are form, meaning, oversimplified explanations, and time-tense relationships. These aspects are crucial in learning this grammar point as it combines various tenses in one sentence and provides different meanings related to the time-tense relationship. As a language instructor, one can not explain the mixed conditionals if they stick to only one of these factors, or they do not explain each of the factors properly. Maule (1988) confirms that the meaning of the used conditional should be emphasized so that learners can comprehend the usage of them in real-life situations. Oversimplified explanations presented in the books make this grammar point even more ambiguous for the learners. According to Celce-Murcia and Larsen Freeman (1999), many textbooks provide oversimplified explanations that cover only three main types of conditionals and do not present adequate information about other types, such as mixed conditionals.

When specific aspects of language are introduced to the students, we can teach a new grammar point with the help of a deductive or inductive approach based on the needs of the students. In the deductive approach, we explain grammar rules first, and then learners can make their examples; however, in the inductive approach, learners are given opportunities to discover the rules by themselves using discovery activities. As J. Harmer (2007) mentioned, "Such discovery activities ask students to do the work rather than having everything handed to them on a plate by the teacher or a grammar/vocabulary book" (p. 82). Activities that focus on both form and meaning are helpful to convey the grammar rules to the learners and encourage them to put the rules into practice.

\section{RESEARCH METHODOLOGY}

The researcher collected qualitative and quantitative data, such as an interview and questionnaire, and created focus-on-form and focus-on-meaning activities, which help the 
learner grasp the form, meaning, and timetense relationship in mixed conditionals. The subject $S$ (the name is disguised) a freshman student of Uzbekistan state world languages university, was struggling to understand the mixed conditionals and use them in everyday life. The research is made in two stages: 1stage. The researcher created the questionnaire and organized an interview to know the subject's ability to understand and use the mixed conditionals. 2-stage. The researcher created activities that can help the learner understand using the mixed conditionals flexibly.

\section{ANALYSIS AND RESULTS}

Being a B2 level learner, $\mathrm{S}$ is aware of many grammatical rules and can use them in written and spoken English. Nevertheless, the learner feels confused while using mixed and third conditionals, even though she knows zero, first, and second conditionals very well. According to the interview with the learner, she answered whether she had any difficulty with any grammar rules, as follows:

FJ: ... Well, another question is which grammar topic is difficult for you to produce?

S: To be honest, one tough topic for me is the conditionals. I always get confused and choose the incorrect one when I am speaking.

FJ: Mm-hmm. So which conditional sentence is the most difficult for you?

S: Unreal conditionals. I think the mixed ones are the most difficult....

After hearing her answer in the interview, I checked her knowledge on this grammar point by giving another question; so, I can make sure she certainly has a problem with the usage of mixed conditionals.

FJ:... If you hadn't entered the university, what would you do now?

S: Well. I think, if I didn't enter the university, I would try again (laughs).

As you can see in the extract from the interview, the learner answered the question using a second conditional sentence, although the question was in the mixed conditional. Being her grammar teacher for a few months, I have encountered several times her confusion about using mixed conditionals during the lessons. So, I realized I need to check her knowledge on mixed conditionals more deeply. Therefore, I told her to write an essay on the topic: "If you could change something in your life, what would you change?" and I told her to use mixed conditional sentences in her essay at least once. She acknowledged she could use some second conditionals; however, she could not use mixed conditionals as it was difficult for her to use them since she does not understand this topic properly.

The next step was to check the learner's awareness of the grammar topic directly with the help of the test. So, I created a specific test to monitor the learner's familiarity with the grammar point. The test includes second conditionals, third conditionals, and mixed conditionals, comprising 25 questions. 
The American Journal of Social Science and Education Innovations

(ISSN - 2689-100x)

Published: April 30, 2021 | Pages: 425-430

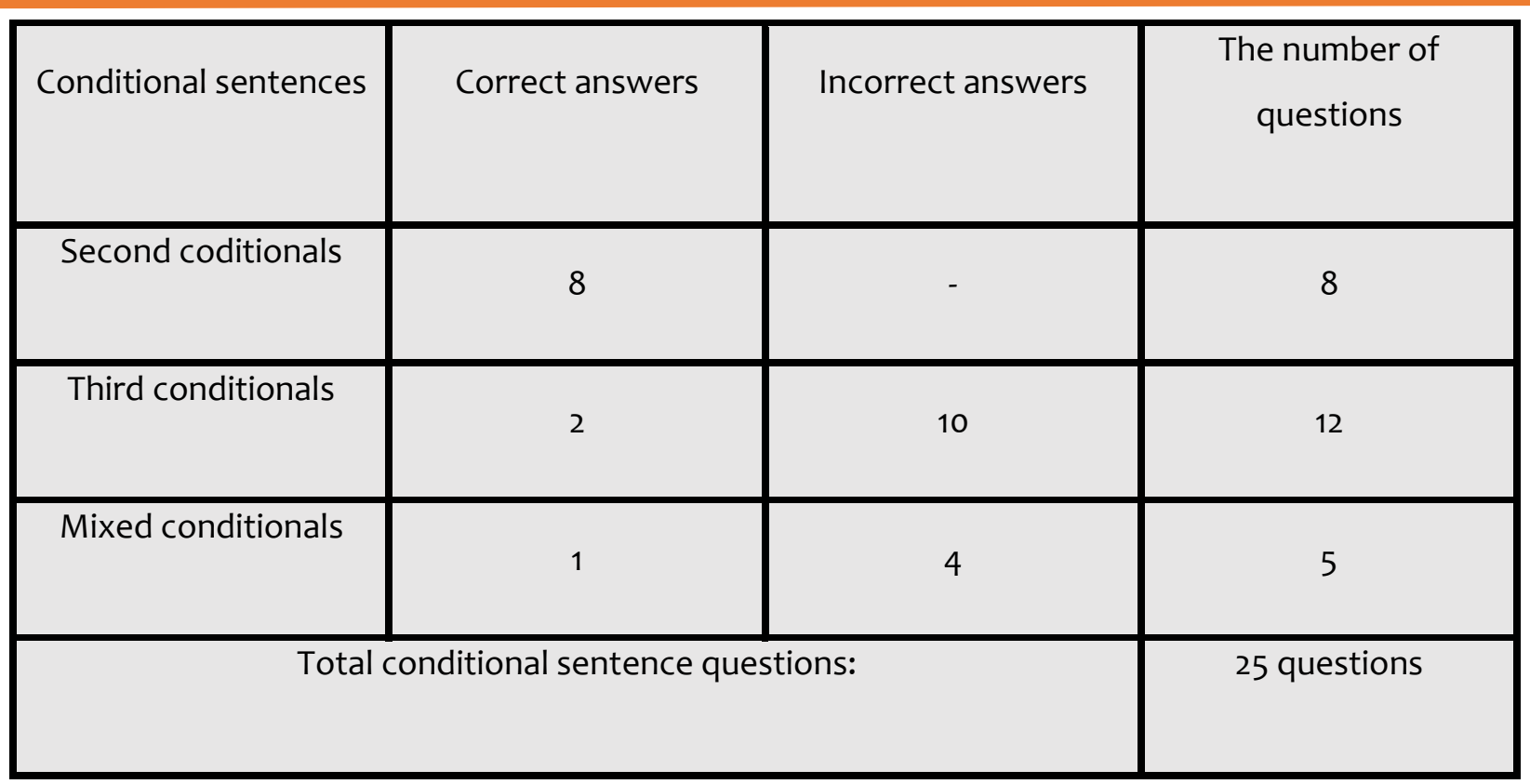

Table 1. The learner's answers to the given questions in the test.

We can see from the table that the learner has no difficulty in doing second conditional tasks and using this grammar point, finding eight correct answers out of eight. The learner made ten mistakes out of twelve third-conditional questions and four mistakes out of five mixedconditional questions. The learner has a problem with comprehending third and mixed conditionals, and also, the learner cannot use them in her speaking. For example, she chose the incorrect answer (b) in question 11.

Q: I ... ... if I'd known about it.

a) would never have gone,

b) would never go.

The correct answer, in this case, is obviously and logically (a) since the action is about the past situation, and the correct sentence would be like this: "I would never have gone if I had known about it." Many similar problems can be seen in other third and mixed conditional sentences, determining that the student gets confused to use these grammar points.
Another example can be question 12, in which the learner cannot use the mixed conditional correctly.

Q12. She ... ... so worried about the operation now if the doctor had explained things better.

a) wouldn't have been,

b) wouldn't be.

The learner chose the answer (a), which is wrong in this sentence. The correct answer to this question is (b), which can be guessed by the signal word now; however, the learner cannot choose the correct one. We can see from these examples, the problem here is that the learner has trouble understanding the form and meaning of the conditional sentences. She made the same mistakes in mixed conditional questions. As we can see in question 21, the learner picked the answer (a) where the correct answer was (b).

Q21. If I had gone to the disco on Saturday night, I ... ... now. 
a) would have been tired

b) would be tired

The reason the learner is facing this problem is that not only there are several types of conditionals, which make learners confused, but also the complexity of the grammar point is too high for EFL learners. The two parts of mixed conditional sentences show a different time- tense relationship with different meanings, and this can be the primary problem for the learner's confusion.

\section{Description of the activities.}

The PPP (Present-Practice-Activate) model of a lesson plan is used along with product, process, and skill activities. This type of lesson plan is very useful in teaching grammar since a language instructor can provide students with many beneficial activities. According to Thornbury (1999), the PPP form represents the accuracy-to-fluency model, with the help of which students can improve both their accuracy and fluency.

The lesson starts with the warm-up activity to activate the students' schema, in which the teacher writes a famous quote written by a well-known French novelist, Gustave Flaubert. The quote comprises a mixed conditional sentence and an explanation in the first conditional. The second and third activities of the lesson are product activities that help students to use and produce the form of the grammar point correctly. Without focus-onform instructions, achieving language proficiency is rather difficult. According to Doughty and William (1998, p.245), language can be learned through form, meaning, and use. The lesson also includes process activities by which students can improve their fluency and communicative skills. These kinds of activities encourage students to focus on the meaning rather than focus on the form only. However, focus-on-meaning activity has been criticized because students' attention is only on meaning, and it may affect the form of sentences that learners use in their speaking (Doughty, 1998). Therefore, learners can benefit from language lessons if they provide both focus-on-form and focus-on-meaning activities.

The lesson also includes a technology-based activity to motivate and stimulate students to learn the grammar point. Using technology in the language learning process strengthens collaborative work among students (Harmer, 2007). Computer-based activities are the best way to manage and monitor students' progress during the lesson, and these kinds of activities provide both teachers and students with a unique experience. Another activity used during the lesson is skill activity by the language instructor can present authentic materials that help learners be able to use the grammar point in everyday life. The lesson is designed carefully in which students can notice the grammar point first, and then they are given opportunities to practice it. According to Schmidt's noticing hypothesis (1994), learners should be given a chance to notice the grammar point rather than explained the grammar topic explicitly. The lesson finishes with a wrap-up activity in which the teacher asks concept checking questions (CCQ) from the students and assigns the homework with the help of another online tool, the Flip grid.

\section{CONCLUSION}

Being a complex grammar topic, mixed conditionals are always the main issue among learners and teachers in the outer-circle countries because of form, meaning, and time- 
tense relationship. Considering the misunderstanding of the topic among learners, language instructors should pay attention to not only focus-on-form activities but also further activities like focus-on-meaning or process and skill activities where learners can use their higher-order thinking skills. With the help of process and skill activities, learners can practice the grammar rule orally, enabling them to realize the meaning and use of mixed conditionals in everyday life.

\section{REFERENCES}

1. Azar, B. S., \& Hagen, S. A. (2009). Understanding and using English grammar. P. 196. White Plains, NY: Pearson Longman.

2. Dooley, J., Evans, V. (1999). Grammarway 4. Pp.73-76. UK. Express Publishing

3. Liz, S., \& John, S. (2009). New Headway, Intermediate, Student's book. Pp. 72-75. Oxford: Oxford University Press.

4. Celce-Murcia, M. and D. Larsen-Freeman. (1999). The Grammar Book: An ESL/EFL Teacher's Course. Heinle \& Heinle.

5. Covitt, R. I. (1976). "Some Problematic Grammar Areas for ESL Teachers." Unpublished M.A. thesis in TESL, UCLA.

6. Doughty C. \& Williams J. (1998). Issues and Terminology., In C. Doughty \& J. Williams (Eds.), Focus on Form in Classroom Second Language Acquisition (pp. 1-11). Cambridge, UK: Cambridge University Press.

7. Doughty C. \& Williams J. (Eds.) (1998). Focus on Form in Classroom Second Language Acquisition. Cambridge, UK: Cambridge University Press.

8. Harmer, J. (2007). How to Teach English. Pearson Education Limited.
9. Maule, D. (1988). "Sorry, But If He Comes, I Go': Teaching Conditionals." ELT Journal, 42/2:117-123.

10. Murphy, R. (2012). English Grammar in Use. 4th ed. Cambridge Univesity Press.

11. Kay, S. \& Jones, V. (2009). New inside out. Macmillan Press.

12. Taylor, J. (1997). "Conditionals and polarity" in A. Athanasiadou and R. Dirven (eds): On Conditionals Again. John Benjamins.

13. Thornbury, S. (1999). How to Teach Grammar. Pearson education Limited.

14. Schmidt, R. (1994). Implicit Learning and the Cognitive Unconcious: of Artifical Grammar and SLA. In N. Ellis (Ed.), Implicit and Explicit Learning of Languages (pp. 165-209). London: Academic Press. 